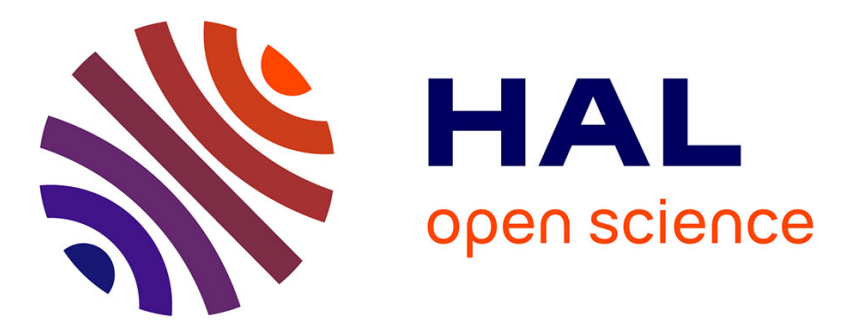

\title{
Genetic effects for yield components and fibre characteristics in upland cotton (Gossypium hirsutum L.) cultivated under salinized $(\mathrm{NaCl})$ conditions
}

\author{
Muhammad Ashraf, Saghir Ahmad
}

\section{- To cite this version:}

Muhammad Ashraf, Saghir Ahmad. Genetic effects for yield components and fibre characteristics in upland cotton (Gossypium hirsutum L.) cultivated under salinized $(\mathrm{NaCl})$ conditions. Agronomie, 2000, 20 (8), pp.917-926. 10.1051/agro:2000168 . hal-00886093

\section{HAL Id: hal-00886093 https://hal.science/hal-00886093}

Submitted on 1 Jan 2000

HAL is a multi-disciplinary open access archive for the deposit and dissemination of scientific research documents, whether they are published or not. The documents may come from teaching and research institutions in France or abroad, or from public or private research centers.
L'archive ouverte pluridisciplinaire HAL, est destinée au dépôt et à la diffusion de documents scientifiques de niveau recherche, publiés ou non, émanant des établissements d'enseignement et de recherche français ou étrangers, des laboratoires publics ou privés. 


\title{
Genetic effects for yield components and fibre characteristics in upland cotton (Gossypium hirsutum L.) cultivated under salinized ( $\mathrm{NaCl})$ conditions
}

\author{
Muhammad ASHRAF*, Saghir AHMAD \\ Institute of Pure and Applied Biology, B.Z. University, Multan 60800, Pakistan
}

(Received 7 December 1999; accepted 5 May 2000)

\begin{abstract}
Genetic effects for yield components and fibre characteristics in cotton were assessed using a complete diallel cross of six cultivars/lines, differing in salt tolerance. The salt tolerance of 36 crosses, including selfs, was assessed in soil salinized with $140 \mathrm{~mol} \cdot \mathrm{m}^{-3} \mathrm{NaCl}$. The variance due to general combining ability (GCA) and specific combining ability (SCA) were highly significant for all the traits studied except monopodia per plant where only SCA was highly significant. This indicated that both additive and dominance gene effects were responsible for the inheritance of different traits, except monopodia per plant. The GCA mean square values higher than those of SCA indicated the pre-dominance of additive effect for all the traits. Considerable heterosis and maternal effects were observed for most of the traits. However, the presence of high additive effects indicates that a significant advancement in salt tolerance is possible through appropriate selection.
\end{abstract}

cotton / genetic components / genetic variation / salt tolerance / diallel crossing design

Résumé - Effets génétiques sur les composantes du rendement et la qualité de la fibre du coton (Gossypium hirsutum L.) cultivé en condition saline. Les effets génétiques pour les composantes du rendement et les caractéristiques de la fibre de coton ont été étudiés dans un croisement diallèle complet entre six cultivars et lignées différant pour leur tolérance au sel $(\mathrm{NaCl})$. Lors de l'expérimentation, les 30 croisements et les 6 autofécondations ont été cultivés, de la quatrième semaine jusqu'à la maturité, en sol irrigué avec une eau à $140 \mathrm{~mol} \cdot \mathrm{m}^{-3} \mathrm{de} \mathrm{NaCl}$. Les variances d'aptitude générale (AGC) et d'aptitude spécifique à la combinaison (ASC) ont été trouvées hautement significatives pour tous les caractères étudiés, à l'exception du nombre de tiges à croissance monopodiale par plante pour lequel seule l'ASC s'est révélée significative. L'importance des carrés moyens d'AGC comparés à ceux d'ASC montrent qu'une part importante

Communicated by Philippe Brabant (Gif-sur-Yvette, France)

* Correspondence and reprints

luaf@fsd.paknet.com.pk

Present address: Department of Botany, University of Agriculture, Faisalabad, Pakistan. 
des effets génétiques est de type additif. De l'hétérosis et des effets maternels ont été observés pour la plupart des caractères. Malgré tout, la prépondérance des effets additifs laisse penser que des progrès sur la tolérance au sel pourront être facilement réalisés grâce à la sélection. Des géniteurs originaires de Porto-Rico ont été identifiés comme source possible de variabilité pour améliorer les cultivars pakistanais.

coton / composantes génétiques / variation génétique / tolérance au sel / projet de croisement diallèle

\section{Introduction}

Cotton is one of the oldest fibre crops. Four species of the genus Gossypium have contributed to a great demand for modern cultivated cotton. Upland cotton (Gossypium hirsutum) and Egyptian cotton (G.barbadense) account for more than 99 per cent of the world supply of raw cotton for factory use. The lint percentage of G.hirsutum is $35-45 \%$ or even more. Some strains of Pakistan have $54 \%$ ginning out-turn and a $30-38 \mathrm{~mm}$ staple length (Khan, personal communication). Gossypium barbadense produces longer fibre $(38 \mathrm{~mm})$ [14]. The share of Gossypium arboreum and Gossypium herbaceum to the total fibre production is less than $1 \%$ because of their short staple lint and low ginning out-turn $[8,14]$. Cotton crop, mainly grown for fibre purpose, is also an important source of vegetable oil among its many other valuable uses $[2,8]$. In Pakistan, cotton production accounts for $24 \%$ of the agricultural sector's output, $60 \%$ of export earnings and over $50 \%$ of edible oil. It is grown on 3.28 million ha. It provides raw material to 500 textile mills, 1135 ginning factories and over 5000 oil expelling units [4].

In Pakistan, the total geographical area is 80 million hectares, of which 33 million are considered suitable for cultivation, but about $6.3 \times 10^{6}$ ha are affected by salinity $[21,30]$. It has been estimated that 40000 ha are annually lost due to salinity in Pakistan that means a loss of US\$ 0.33 billion [29]. This environmental hazard has considerably affected the production of all crops including the major cash crop, cotton [38]. The threshold salinity (the maximum salinity level at which a crop has no yield loss) of cotton is $7.7 \mathrm{dS} \cdot \mathrm{m}^{-1}$, and 50 per cent reduction in growth occurs at $17 \mathrm{dS} \cdot \mathrm{m}^{-1}$ of soil salinity [25].
Although a great achievement in increasing yield per hectare has been made during the past few decades, still Pakistan lags behind the advanced cotton growing countries of the world (Australia, USA, Uzbekistan, China, etc.). Besides the other constraints responsible for low yield, salinity is one which cannot be ignored at all and needs urgent attention of plant scientists as this crop is adversely affected by high concentrations of ions in the growth medium [25]. High root zone salinity has been reported to adversely affect lint percentage, staple length, fibre fineness and fibre maturity $[1,13]$.

Considerable efforts have been made in the past few decades for the development of salt tolerant varieties of different crops through selection and breeding [5, 6, 10, 12, 23, 28, 32, 33, 36, 39]. The identification of variation for salt tolerance is a pre-requisite for evolving crop cultivars for salinity tolerance through selection and breeding. If variation does not exist for the character being studied, the chances of improvement of the character through various breeding methods are meagre. The introduction of mathematical models into classical Mendelian genetics has played an important role in understanding the pattern of inheritance of a trait. Therefore, to begin with breeding efforts, information regarding the mode of inheritance of a particular trait is very important.

While aiming to select a desirable genotype, the simple technique of crossing/hybridizing of contrasting parents has facilitated breeders to identify the genetics of simply inherited characters. Yates [40] proposed a series of crosses in all possible combinations among parental lines. This diallel technique has been widely used by different breeders for the identification of genes of more complex characters and selecting parental lines for their 
utilization in crossing programmes for developing new varieties [18-20, 22, 24, 39].

Despite the considerable importance of understanding the genetic basis of variation for salinity tolerance $[15,37]$, only a few studies, indicating the genetic basis of salt tolerance, can be deciphered in the literature. For instance, in citrus root stock [16] and in rice [27], it was found that salt tolerance in these species are under polygenic control. In sorghum, salt tolerance during germination and seedling growth stages was found to be controlled by complementary gene action, incomplete dominance and dominance or additive effects of several genes [31]. Similarly, in alfalfa [7, 28], in seven grass species [10] and in pearl millet [9], it was found that salt tolerance in these species is highly heritable. In another study, Azhar and McNeilly [12] reported that both additive and dominant genes appeared to be important for variation of salt tolerance in sorghum. In cotton, Ledbetter [23] estimated narrow sense heritability for salt tolerance to be 0.38 during germination and emergence.

These studies, therefore, reveal that differences in yield performance under saline conditions are genetically controlled and varieties can be bred which can withstand saline conditions. The knowledge about mode of inheritance and estimation of components of the genetic system under saline conditions is very important. The present study was, therefore, conducted to investigate the genetic effects of some salinity related characteristics, e.g. seed cotton yield, yield components and fibre traits in cotton.

\section{Materials and methods}

The seeds of six cultivars/lines of cotton, B-557, MNH-156, MNH-147 (all three originated from Pakistan), Culture 604-4, Culture 728-4 (both originally from Puerto Rico), and B-1580-ne (from USA) were obtained from the Central Cotton Research Institute Multan, Pakistan. B-557, MNH156, and Culture 728-4 were salt tolerant whereas MNH-147, Culture 604-4, and B-1580-ne were salt sensitive. The seed cotton yield per plant (g) of the six cultivars/lines under normal non-saline conditions [3] was: B-557 $=26.4$; MNH-156 = 32.6; Culture 728-4 $=29.8$; MNH-147 $=28.2$; Culture $604-4=29.7$; B-1589-ne $=14.1$. These parental cultivars/lines were selected on the basis of their response to salinity at different growth stages [3]. They were grown in normal soil under natural field conditions during the month of June, 1997. At flowering, during August-September, the parental lines were crossed in a complete $6 \times 6$ diallel fashion. Flowers were hand emasculated in the evening and all necessary precautions were taken to avoid alien pollen contamination. For this purpose, after emasculation the flowers were covered with porous polythene bags. As the stigma became receptive next day of emasculation, the anthers from the male parent were collected in sterilized Petri dishes. Pollens from anthers were dusted on stigma of emasculated female parents which were covered again with the respective polythene bag until boll formation. Hands and all equipment in use were sterilized with absolute alcohol before conducting the next pollination. At maturity, crossed bolls were picked and seed cotton was ginned with a roller ginning machine.

For assessing the response of $F_{1}$ hybrids and their parents to $\mathrm{NaCl}$ salinity, the material was grown in soil salinized with $140 \mathrm{~mol} \cdot \mathrm{m}^{-3} \mathrm{NaCl}$. The salt treatment was started after four weeks of normal growth and continued till maturity. The experiment comprised 36 genotypes with 4 blocks. At maturity, data were recorded for seed cotton yield, bolls per plant, monopodia per plant, sympodia per plant, plant height, seed oil content, ginning out-turn, staple length, fibre fineness, fibre maturity and fibre strength.

\subsection{Statistical analysis}

The data collected were subjected to analyses of variance following Steel and Torrie [35]. The combining ability analysis was carried out using Method II and Model II of Griffing [17], i.e. including parents, their $\mathrm{F}_{1 \mathrm{~s}}$ and reciprocals. Genetic components of variation were also obtained using 
the procedures described by Hayman [18] and Mather and Jinks [26], and as given by Singh and Chaudhry [34]. In the following section, we will only express the results obtained with Griffing's method because the two approaches gave consistent results. Nevertheless, in the discussion we will sometimes refer to the results obtained following Hayman [18] and Mather and Jinks [26].

\section{Results}

The analysis of variance (Tab. I) revealed highly significant differences among the genotypes for all the traits studied. It thus indicated an adequate amount of variability present in the parental material. The significant genotypic variance was further partitioned into variance due to general combining ability (GCA), specific combining ability (SCA) and reciprocal effects.
The variance due to GCA and SCA were highly significant for all the traits studied, except for monopodia per plant where only SCA was highly significant (Tab. I). This indicated that both additive and dominance gene effects were responsible for the inheritance of seed cotton yield, bolls per plant, sympodia per plant, plant height, seed oil content, ginning out-turn, staple length, fibre fineness (lower values indicate high fibre fineness), fibre maturity and fibre strength whereas only dominance gene effects for monopodia per plant. The GCA mean square values higher than those of SCA indicated the pre-dominance of an additive effect for all the traits studied except monopodia per plant for which the GCA variance was higher than that of SCA but it was not significant. The reciprocal effects for all the traits were highly significant except seed oil content. The significant reciprocal effects indicated the importance of selection for male and female parents in these traits.

Table I. Mean squares from analysis of variance of data for seed cotton yield, yield components and fibre characteristics of 36 crosses, including selfs, and $\mathrm{F}_{1 \mathrm{~s}}$ of cotton when grown in soil salinized with $140 \mathrm{~mol} \cdot \mathrm{m}^{-3} \mathrm{NaCl}$.

\begin{tabular}{lccccccc}
\hline $\begin{array}{l}\text { Source } \\
\text { of variation }\end{array}$ & $\begin{array}{c}\text { Degree } \\
\text { of freedom }\end{array}$ & $\begin{array}{c}\text { Seed cotton } \\
\text { yield }\end{array}$ & $\begin{array}{c}\text { Bolls } \\
\text { per plant }\end{array}$ & $\begin{array}{c}\text { Monopodia } \\
\text { per plant }\end{array}$ & $\begin{array}{c}\text { Sympodia } \\
\text { per plant }\end{array}$ & $\begin{array}{c}\text { Plant } \\
\text { height }\end{array}$ & $\begin{array}{c}\text { Seed oil } \\
\text { content }\end{array}$ \\
\hline Replications & 3 & $8.3 \mathrm{~ns}$ & $2.49 \mathrm{~ns}$ & $0.017 \mathrm{~ns}$ & $10.08 \mathrm{~ns}$ & $141.51^{*}$ & $0.627 \mathrm{~ns}$ \\
Genotypes & 35 & $280.52^{* * *}$ & $54.25^{* * *}$ & $0.58^{* * *}$ & $32.1 * * *$ & $1281.2^{* * *}$ & $3.853^{* * *}$ \\
GCA & 5 & $353.86^{* * *}$ & $70.95^{* * *}$ & $0.23 \mathrm{~ns}$ & $24.92^{* * *}$ & $1357.60^{* * *}$ & $3.51^{* * * *}$ \\
SCA & 15 & $28.96^{* * *}$ & $4.61 * * *$ & $0.15^{* * *}$ & $5.20^{* * *}$ & $237.02^{* * *}$ & $0.69 * * *$ \\
Reciprocal & 15 & $16.72^{* *}$ & $3.38^{* * * *}$ & $0.12^{* * *}$ & $5.21^{* * *}$ & $12.23 * * *$ & $0.39 \mathrm{~ns}$ \\
Error & 105 & 27.38 & 4.68 & 0.09 & 5.31 & 48.93 & 0.91 \\
\hline
\end{tabular}

\begin{tabular}{lclllll}
\hline $\begin{array}{l}\text { Source } \\
\text { of variation }\end{array}$ & $\begin{array}{c}\text { Degree } \\
\text { of freedom }\end{array}$ & $\begin{array}{l}\text { Ginning } \\
\text { out-turn }\end{array}$ & $\begin{array}{l}\text { Staple } \\
\text { length }\end{array}$ & $\begin{array}{c}\text { Fibre } \\
\text { fineness }\end{array}$ & $\begin{array}{c}\text { Fibre } \\
\text { maturity }\end{array}$ & $\begin{array}{c}\text { Fibre } \\
\text { strength }\end{array}$ \\
\hline Replications & 3 & $29.43^{* * *}$ & $0.154 \mathrm{~ns}$ & $0.004 \mathrm{~ns}$ & $0.4 \mathrm{~ns}$ & $3.12^{*}$ \\
Genotypes & 35 & $79.2 * * *$ & $4.15^{* * *}$ & $0.272^{* * *}$ & $39.04 * * *$ & $41.44^{* * *}$ \\
GCA & 5 & $78.01^{* * *}$ & $5.80^{* * *}$ & $0.42^{* * *}$ & $40.00^{* * *}$ & $49.75^{* * *}$ \\
SCA & 15 & $14.98^{* * *}$ & $0.28^{* * *}$ & $0.007 * * *$ & $5.16^{* * *}$ & $2.93^{* * *}$ \\
Reciprocal & 15 & $5.20^{* * *}$ & $0.21^{* *}$ & $0.01 * * *$ & $4.29 * * *$ & $4.66^{* * *}$ \\
Error & 105 & 3.11 & 0.348 & 0.007 & 1.021 & 1.034 \\
\hline
\end{tabular}

$*, * *, * * *=$ Significant at $0.05,0.01$ and 0.001 levels, respectively.

$\mathrm{ns}=$ not significant 
Table II. General combining ability effects for seed cotton yield, yield components and fibre characteristics of 36 crosses, including selfs, and $\mathrm{F}_{1 \mathrm{~s}}$ of cotton when grown in soil salinized with $140 \mathrm{~mol} \cdot \mathrm{m}^{-3} \mathrm{NaCl}$.

\begin{tabular}{lrrrrrrrrrrrr}
\hline Genotypes & $\begin{array}{c}\text { Seed cotton } \\
\text { yield }\end{array}$ & $\begin{array}{c}\text { Bolls } \\
\text { per plant }\end{array}$ & $\begin{array}{c}\text { Monopodia } \\
\text { per plant }\end{array}$ & $\begin{array}{c}\text { Sympodia } \\
\text { per plant }\end{array}$ & $\begin{array}{c}\text { Plant } \\
\text { height }\end{array}$ & $\begin{array}{c}\text { Seed oil } \\
\text { content }\end{array}$ & $\begin{array}{c}\text { Ginning } \\
\text { out-turn }\end{array}$ & $\begin{array}{c}\text { Staple } \\
\text { length }\end{array}$ & $\begin{array}{c}\text { Fibre } \\
\text { fineness }\end{array}$ & $\begin{array}{c}\text { Fibre } \\
\text { maturity }\end{array}$ & $\begin{array}{c}\text { Fibre } \\
\text { strength }\end{array}$ \\
\hline $\mathrm{B}-557$ & 4.310 & 1.796 & 0.185 & 1.658 & 14.368 & 0.647 & -2.426 & 0.454 & 0.176 & 0.728 & 1.997 \\
$\mathrm{~B}-1580$ & -7.065 & -3.356 & -0.210 & -2.638 & -13.980 & -0.476 & 1.256 & -0.471 & -0.193 & -2.142 & -1.924 \\
$\mathrm{C}-728$ & 4.196 & 1.546 & 0.088 & 0.708 & 3.718 & 0.297 & -3.126 & 0.8 & 0.178 & 2.106 & 1.508 \\
$\mathrm{C}-604$ & -3.477 & -1.252 & -0.088 & -0.088 & -5.320 & -0.420 & 1.068 & -0.535 & -0.060 & -1.297 & -1.365 \\
$\mathrm{MNH}-147$ & -3.840 & -1.638 & -0.025 & -0.047 & -7.170 & -0.549 & 3.726 & -0.842 & -0.233 & -1.317 & -2.215 \\
$\mathrm{MNH}-156$ & 5.875 & 2.904 & 0.05 & 0.408 & 8.383 & 0.503 & -0.199 & 0.594 & 0.132 & 1.922 & 1.999 \\
\hline $\mathrm{SE}\left(\mathrm{G}_{\mathrm{i}}\right)$ & 0.690 & 0.285 & 0.040 & 0.304 & 0.922 & 0.125 & 0.232 & 0.078 & 0.012 & 0.133 & 0.134 \\
$\mathrm{SE}\left(\mathrm{G}_{\mathrm{i}}-\mathrm{G}_{\mathrm{j}}\right)$ & 1.068 & 0.442 & 0.062 & 0.470 & 1.428 & 0.194 & 0.360 & 0.120 & 0.017 & 0.207 & 0.208 \\
$\mathrm{SE}\left(\mathrm{R}_{\mathrm{ij}}\right)$ & 1.850 & 0.765 & 0.107 & 0.815 & 2.473 & 0.336 & 0.624 & 0.208 & 0.029 & 0.357 & 0.359 \\
\hline
\end{tabular}

$\operatorname{SE}\left(\mathrm{G}_{\mathrm{i}}\right)=$ standard error for any GCA effect.

$\mathrm{SE}\left(\mathrm{G}_{\mathrm{i}}-\mathrm{G}_{\mathrm{j}}\right)=$ standard error of the difference between any two GCA effects.

$\mathrm{SE}\left(\mathrm{R}_{\mathrm{ij}}\right)=$ standard error of any reciprocal GCA.

The GCA effects for each trait are presented in Table II. The best general combiner with maximum GCA was MNH-156 for seed cotton yield, bolls per plant and fibre strength; B-557 for monopodia per plant, sympodia per plant, plant height, seed oil content; MNH-147 for ginning out-turn, and C-728 for staple length and fibre maturity. The genotype MNH-147 was the best general combiner for fibre fineness with maximum negative GCA value.

The mean results of different growth and fibre attributes (Tabs. III a and III b) from progeny plants grown in soil salinized with $140 \mathrm{~mol}$ $\mathrm{NaCl} \cdot \mathrm{m}^{-3}$ are presented for assessment of performance of different cross combinations and parental genotypes. The salt tolerant line B-557 from Pakistan had a small heterosis for seed cotton yield (Tab. III a) when it was crossed with the salt tolerant cv. MNH-156 or salt sensitive B-1580. However, considerable heterosis was observed when it was crossed with the other salt tolerant line C-728-4. Maternal effects were evident when it was crossed with the salt sensitive lines, B-1580 and MNH-147. The other salt tolerant line C-728, originally from Puerto Rico, showed significant heterosis when it was crossed with the salt tolerant lines, B-557 and MNH-156, and salt sensitive lines, C-604 and MNH-147. Maternal effects of
C-728 were observed in its crosses with all three salt sensitive lines. The third salt tolerant line MNH-156 also showed heterosis when it was crossed with the salt tolerant lines, B-557 and C-728, and salt sensitive line C-604. The maternal effect of this line in seed cotton yield was only found when it was crossed with the salt sensitive C-604. The salt sensitive line B-1580, originally from USA, did not show heterosis with either line in seed yield. However, its maternal effects were significant in its crosses with all three salt tolerant lines. Small heterosis was found when the salt sensitive line C-604 was crossed with the other salt sensitive lines, B-1580 and MNH-147, and maternal effects of this line were only significant in its crosses with the two salt tolerant lines, C-728 and MNH-156. The third salt sensitive line, MNH-147 showed a small heterosis in seed cotton yield with the other two salt sensitive lines and the maternal effect of this line was only found in its cross with the salt tolerant line, C-728.

In bolls per plant (Tab. III a), only one salt tolerant line MNH-156 showed heterosis and maternal effects in its crosses with two salt tolerant lines, B-557 and C-728, and one salt sensitive line, C-604. Although the other two salt tolerant lines did not have heterosis with either line, their maternal effects 
Table III a. Mean data for seed cotton yield, bolls per plant, monopodia per plant, sympodia per plan plant height and seed oil content of $F_{1}$ of cotton when grown in soil salinized with $140 \mathrm{~mol} \cdot \mathrm{m}^{-3} \mathrm{NaCl}$.

\begin{tabular}{|c|c|c|c|c|c|c|}
\hline Parents/F ${ }_{1}$ & $\begin{array}{c}\text { Seed cotton } \\
\text { yield }\left(\mathrm{g} \cdot \text { plant }^{-1}\right)\end{array}$ & $\begin{array}{c}\text { Bolls } \\
\text { per plant }\end{array}$ & $\begin{array}{l}\text { Monopodia } \\
\text { per plant }\end{array}$ & $\begin{array}{l}\text { Sympodia } \\
\text { per plant }\end{array}$ & $\begin{array}{l}\text { Plant height } \\
\text { (cm) }\end{array}$ & $\begin{array}{c}\text { Seed oil } \\
\text { content }(\%)\end{array}$ \\
\hline B-557 & 24.9 & 11.2 & 1.15 & 14.5 & 89.2 & 17.2 \\
\hline B-1580 (ne) & 4.4 & 2.3 & 0.40 & 7.7 & 42.2 & 17.5 \\
\hline C-604-4 & 6.8 & 4.7 & 0.60 & 14.6 & 57.4 & 16.6 \\
\hline C-728-4 & 23.4 & 11.9 & 0.72 & 16.7 & 79.7 & 18.5 \\
\hline MNH 147 & 8.2 & 4.7 & 1.20 & 11.15 & 51.3 & 16.7 \\
\hline MNH 156 & 19.1 & 9.0 & 0.60 & 13.5 & 76.9 & 18.4 \\
\hline B557xB1580 & 19.1 & 9.0 & 0.60 & 13.5 & 76.9 & 17.5 \\
\hline B557xC604-4 & 17.0 & 8.8 & 1.07 & 16.0 & 86.7 & 17.3 \\
\hline $\mathrm{B} 557 \mathrm{xC} 728-4$ & 31.3 & 13.0 & 0.45 & 15.0 & 100.0 & 18.5 \\
\hline B557xMNH147 & 16.7 & 7.4 & 1.05 & 17.3 & 91.8 & 16.9 \\
\hline B577xMNH156 & 26.2 & 10.9 & 1.05 & 17.6 & 80.0 & 18.7 \\
\hline B1580xB557 & 10.6 & 5.2 & 0.95 & 8.9 & 58.9 & 16.8 \\
\hline B1580xC604-4 & 9.8 & 2.3 & 0.75 & 10.9 & 35.2 & 16.1 \\
\hline B1580xC728-4 & 6.0 & 2.7 & 0.75 & 9.0 & 44.4 & 16.7 \\
\hline B1580xMNH147 & 13.0 & 4.3 & 0.55 & 14.2 & 34.0 & 14.9 \\
\hline B1580xMNH156 & 18.7 & 5.3 & 0.57 & 10.9 & 40.6 & 17.1 \\
\hline C604-4xB557 & 16.8 & 12.9 & 1.20 & 11.7 & 49.0 & 16.3 \\
\hline C604-4xB1580 & 8.3 & 7.1 & 0.40 & 10.5 & 50.5 & 16.5 \\
\hline C604-4xC728-4 & 18.3 & 3.8 & 0.50 & 12.2 & 56.7 & 16.9 \\
\hline C604-4xMNH147 & 11.2 & 7.7 & 0.70 & 16.0 & 47.2 & 15.7 \\
\hline C604-4xMNH156 & 13.3 & 5.4 & 0.67 & 11.5 & 58.5 & 16.4 \\
\hline C728-4xB557 & 28.2 & 6.7 & 1.23 & 14.0 & 65.7 & 18.0 \\
\hline C728-4xB1580 & 14.3 & 13.0 & 1.10 & 9.5 & 43.7 & 16.2 \\
\hline C728-4xC604-4 & 25.1 & 2.1 & 1.20 & 14.0 & 50.7 & 15.2 \\
\hline C728-4xMNH147 & 24.9 & 10.8 & 1.70 & 11.9 & 53.7 & 17.0 \\
\hline C728-4xMNH156 & 30.8 & 9.3 & 1.07 & 11.5 & 67.0 & 16.8 \\
\hline MNH147xB557 & 12.2 & 6.1 & 1.15 & 15.4 & 46.5 & 16.1 \\
\hline MNH147xB1580 & 11.8 & 6.9 & 0.20 & 8.7 & 48.5 & 15.8 \\
\hline MNH147xC604-4 & 11.8 & 6.4 & 0.60 & 11.2 & 54.0 & 16.7 \\
\hline MNH147xC728-4 & 11.1 & 4.9 & 0.50 & 13.9 & 50.2 & 16.6 \\
\hline MNH147xMNH156 & 16.4 & 8.5 & 0.40 & 10.3 & 58.0 & 17.2 \\
\hline MNH156xB557 & 33.1 & 15.5 & 0.90 & 14.8 & 81.5 & 18.4 \\
\hline MNH156xB1580 & 14.2 & 7.2 & 0.60 & 10.02 & 58.0 & 16.0 \\
\hline MNH156xC604-4 & 22.4 & 11.7 & 0.40 & 9.0 & 75.5 & 16.5 \\
\hline MNH156xC728-4 & 32.6 & 15.2 & 0.80 & 17.4 & 96.0 & 18.4 \\
\hline MNH156xMNH147 & 17.7 & 8.7 & 0.30 & 11.7 & 70.0 & 16.9 \\
\hline Genotype mean squares & $280.5^{* * *}$ & $54.3 * * *$ & $0.58 * * *$ & $32.1 * * *$ & $1281.2 * * *$ & $3.4 * * *$ \\
\hline ! LSD $5 \%$ & 7.4 & 3.06 & 0.424 & 3.26 & 9.89 & 1.22 \\
\hline
\end{tabular}

*** significant at the $0.1 \%$ level.

! LSD 5\%= Least significant difference at the $5 \%$ level.

were significant when crossed with all salt tolerant lines and two salt sensitive lines, B-1580 and MNH-147. The salt sensitive line C-604 revealed heterosis when crossed with the salt tolerant B-557 and the salt sensitive B-1580, and MNH-147 when crossed with the salt sensitive B-1580.

In monopodia per plant, the two salt tolerant lines, B-557 and MNH-156 did not show heterosis 
Table III b. Mean data for ginning out-turn, staple length, fibre fineness, fibre maturity and fibre strength of $F_{1}$ of cotton when grown in soil salinized with $140 \mathrm{~mol} \cdot \mathrm{m}^{-3} \mathrm{NaCl}$.

\begin{tabular}{|c|c|c|c|c|c|}
\hline Parents/F $\mathrm{F}_{1}$ & $\begin{array}{l}\text { Ginning out-turn } \\
(\%)\end{array}$ & $\begin{array}{l}\text { Staple length } \\
(\mathrm{mm})\end{array}$ & $\begin{array}{l}\text { Fibre fineness } \\
\quad(m . n . v)\end{array}$ & $\begin{array}{c}\text { Fibre maturity } \\
(\%)\end{array}$ & $\begin{array}{l}\text { Fibre strength } \\
\quad \text { (tppsi) }\end{array}$ \\
\hline B-557 & 42.7 & 24.9 & 3.9 & 73.4 & 85.7 \\
\hline B-1580 & 49.1 & 23.9 & 3.1 & 68.3 & 82.6 \\
\hline C-604-4 & 49.1 & 22.6 & 3.3 & 67.9 & 84.0 \\
\hline C-728-4 & 45.0 & 25.2 & 3.7 & 74.9 & 88.8 \\
\hline MNH 147 & 54.0 & 22.6 & 3.0 & 70.3 & 81.4 \\
\hline MNH 156 & 48.9 & 25.3 & 3.3 & 73.7 & 75.0 \\
\hline B557xB1580 & 40.9 & 24.8 & 3.5 & 75.2 & 88.8 \\
\hline B557xC604-4 & 41.9 & 24.3 & 3.6 & 68.6 & 86.8 \\
\hline B557xC728-4 & 38.2 & 25.6 & 4.0 & 77.8 & 90.9 \\
\hline B557xMNH147 & 51.8 & 25.0 & 3.5 & 73.3 & 70.1 \\
\hline B577xMNH156 & 45.2 & 25.1 & 3.7 & 75.7 & 89.2 \\
\hline B1580xB557 & 47.4 & 23.6 & 3.1 & 68.7 & 82.0 \\
\hline B1580xC604-4 & 56.1 & 22.7 & 3.1 & 67.4 & 79.3 \\
\hline B1580xC728-4 & 41.1 & 24.1 & 3.4 & 72.3 & 83.6 \\
\hline B1580xMNH147 & 57.2 & 22.4 & 2.9 & 68.9 & 78.2 \\
\hline B1580xMNH156 & 42.7 & 23.2 & 3.5 & 74.8 & 80.7 \\
\hline C604-4xB557 & 46.3 & 23.9 & 3.7 & 74.7 & 82.8 \\
\hline C604-4xB1580 & 51.1 & 23.5 & 3.4 & 71.3 & 80.4 \\
\hline C604-4xC728-4 & 44.1 & 23.8 & 3.6 & 74.5 & 82.9 \\
\hline C604-4xMNH147 & 47.0 & 23.0 & 3.1 & 73.9 & 80.5 \\
\hline C604-4xMNH156 & 46.0 & 24.0 & 3.4 & 74.6 & 83.5 \\
\hline C728-4xB557 & 39.3 & 26.2 & 3.8 & 81.3 & 86.4 \\
\hline C $728-4 \times B 1580$ & 41.4 & 25.0 & 3.4 & 74.4 & 82.2 \\
\hline C728-4xC604-4 & 44.4 & 24.4 & 3.5 & 75.9 & 83.2 \\
\hline C728-4xMNH147 & 45.4 & 23.7 & 3.4 & 71.5 & 82.4 \\
\hline C728-4xMNH156 & 45.4 & 25.8 & 3.6 & 76.7 & 86.3 \\
\hline MNH147xB557 & 42.8 & 23.2 & 3.4 & 72.5 & 82.5 \\
\hline MNH147xB1580 & 53.0 & 22.3 & 3.1 & 70.0 & 80.4 \\
\hline MNH147xC604-4 & 50.1 & 23.4 & 3.2 & 73.0 & 80.8 \\
\hline MNH147xC728-4 & 45.6 & 23.9 & 3.5 & 73.7 & 83.2 \\
\hline MNH147xMNH156 & 45.7 & 23.9 & 3.4 & 74.0 & 83.2 \\
\hline MNH156xB557 & 44.8 & 24.8 & 3.7 & 76.5 & 89.5 \\
\hline MNH156xB1580 & 45.3 & 24.3 & 3.4 & 73.6 & 86.0 \\
\hline MNH156xC604-4 & 46.4 & 24.6 & 3.4 & 73.9 & 85.2 \\
\hline MNH156xC728-4 & 46.7 & 25.8 & 3.8 & 76.5 & 89.2 \\
\hline MNH156xMNH147 & 50.1 & 24.7 & 3.3 & 74.4 & 85.7 \\
\hline Genotype mean squares & $79.2 * * *$ & $4.15^{* * *}$ & $0.27 * * *$ & $39.04 * * *$ & $41.4 * * *$ \\
\hline !LSD $5 \%$ & 2.49 & 0.83 & 0.118 & 0.71 & 1.44 \\
\hline
\end{tabular}

*** significant at the $0.1 \%$ level.

! LSD 5\%= Least significant difference at the 5\% level.

with either line and the latter line also did not have a maternal effect (Tab. III a). However, the maternal effect of B-557 was evident in its crosses with the salt tolerant line $\mathrm{C}-728$ and the salt sensitive
B-1580. It is interesting to note that the salt tolerant line C-728 had significant heterosis and maternal effects in all crosses. The two salt sensitive lines B1580 and C-604 showed heterosis when crossed 
with the salt tolerant lines C-728 and B-557, respectively, whereas the other salt sensitive line MNH-147 did not show heterosis in either cross.

The cross combinations for sympodia per plant (Tab. III a) show that the two salt tolerant lines, C-728 and MNH-156 did not have heterosis in either cross, although the maternal effects of both lines were significant in their own reciprocal crosses. In contrast, the other salt tolerant line B-557 had a significant heterosis when crossed with the salt tolerant MNH-156 and the salt sensitive $\mathrm{MNH}-147$, and the maternal effects of this line were found in its crosses with the two salt sensitive lines, B-1580 and C-604. The hybrid vigour of the two salt sensitive lines, B-1580 and C-604 was evident in their crosses with the salt tolerant C-728 and the salt sensitive B-1580, respectively. In contrast, the third salt sensitive line MNH-147 did not reveal heterosis in either cross.

In plant height (Tab. III a), the salt tolerant line B-557 showed heterosis and maternal effects when it was crossed with the salt tolerant C-728 and the two salt sensitive lines, C-604 and MNH-147. The salt tolerant MNH-156 also showed both heterosis and maternal effects in plant height when crossed with the salt tolerant C-728 and the salt sensitive C-604. The other salt tolerant line C-728 did not show heterosis in either cross, and its maternal effect could be discerned only in its cross with the salt tolerant line MNH-156. All three salt sensitive lines had no heterosis in either cross combination in plant height. In oil content, neither heterosis nor maternal effects were detected in all cross combinations (Tab. III a).

Heterosis and maternal effects in some cross combinations in fibre characteristics are evident from the data presented in Table III $b$. In ginningout-turn, only one salt tolerant line B-557 showed heterosis when it was crossed with the salt sensitive line MNH-147, but it showed significant maternal effects when crossed with all three salt sensitive lines. In contrast, the other two salt tolerant lines, C-728 and MNH-156 did not show heterosis in either cross combination, and the maternal effect of the latter line was significant with the salt sensitive line MNH-147. Of the salt sensitive lines, only B-1580 exhibited heterosis when it was crossed with the other two salt sensitive lines.

In staple length and fibre fineness (Tab. III b), neither salt tolerant nor salt sensitive lines showed heterosis or maternal effects except the salt tolerant line B-557 which had significant heterosis and maternal effect in staple length when it was crossed with the salt sensitive MNH-147.

In fibre maturity (Tab. III b) all three salt tolerant lines showed heterosis. For instance, B-557 exhibited heterosis in its crosses with the salt tolerant line C-728 and the salt sensitive B-1580, C-728 with the salt tolerant B-557 and the salt sensitive B-1580 and C-604, and MNH-156 with the salt tolerant B-557 and the salt sensitive MNH-147. The salt sensitive line C-604 showed hybrid vigour in all crosses with salt tolerant or salt sensitive lines, but in contrast, the other salt sensitive line B-1580 showed heterosis with the salt tolerant MNH-156. The salt sensitive MNH-147 revealed heterosis with the other salt sensitive line C-604.

In fibre strength (Tab. III b), the salt tolerant line MNH-156 showed heterosis in all cross combinations, whereas B-557 showed it with all salt tolerant lines and one salt sensitive B-1580, and C-728 with the salt tolerant $\mathrm{MNH}-156$. B-557 had maternal effects in all cross combinations except with the salt tolerant $\mathrm{MNH}-156$. The other salt tolerant line C-728 showed a maternal effect with the salt tolerant B-557, and MNH-156 with the salt sensitive B-1580. Of the salt sensitive lines, both MNH-147 and C-604 revealed heterosis when crossed with the salt tolerant line MNH-156.

\section{Discussion - Conclusion}

The primary objective of the present study was to estimate the components of genetic variation in cotton and whether these components could be effective for the improvement of the salt tolerance trait in cotton. However, it is evident that a trait can only be improved if different favourable genes can be recombined in a new genotype [40]. Therefore, the pattern of inheritance of salt tolerance of cotton was assessed by measuring seed cotton yield, yield 
components, seed oil content, and fibre characteristics, from plants grown in salinized soil.

Both analyses carried out following Griffing [17] and Hayman [18] showed that both additive and non-additive gene effects were found to be responsible in controlling the expression of salt tolerance. Thus the genetic system of salt tolerance in cotton seems slightly complicated as has also been reported for some other crops, e.g. rice [5, 27], grain sorghum [12, 31] and chick pea [39]. Nevertheless, the high additive component of variation for seed cotton yield, bolls per plant, plant height, staple length, fibre fineness, and fibre maturity suggests that significant improvement in these characteristics in response to soil salinity is possible through further selection and breeding. The earlier studies on salt tolerance in different crop species have also revealed that additive variance was very useful for improvement of this character. For instance, salt tolerance in Medicago sativa was improved as a result of high heritable variation $[6$, 11, 28]. Similarly, Azhar and McNeilly [12] found that salt tolerance in sorghum is significantly heritable (0.5). The high additive component of genetic variation for salt tolerance in pulses was also reported by Waheed [39]. In cotton, Ledbetter [23] showed narrow sense heritability of 0.38 for salt tolerance during germination and emergence.

From Tables III $a$ and III $b$ it is evident that the response of some of $\mathrm{F}_{1}$ progenies to $\mathrm{NaCl}$ salinity was significantly better than the others. These results are in close conformity with the findings of Strogonov [36] who found a 7-43 percent increase in seed cotton yield of the hybrid resulting from a cross of salt tolerant and salt sensitive selections, under saline conditions. In addition to Pakistani lines which had high performance under saline conditions, C-728, originally from Puerto Rico, appears well adapted to salt stress. Thus it could be used as a new source of variability for enhancing the yield of Pakistani lines under salt stress, and principally as a female parent because it revealed strong positive maternal effects when crossed with salt sensitive lines. The other line C-604, also from Puerto Rico, although salt sensitive in all yield and fibre characteristics under saline medium, appears a good combiner with Pakistani lines. So even if it is salt sensitive it may also be a good source of genes. Similarly, the other salt sensitive line B1580 , originally from USA is a good combiner with Pakistani lines in most of the fibre and yield characteristics.

It can be concluded that the additive genetic component of salt tolerance is high in the cotton cultivars/lines used for the present study, which suggests that significant advancement in this character is possible through selection and breeding.

\section{References}

[1] Abdullah Z., Ahmad R., Salinity induced changes in the reproductive physiology of cotton plants, in: Ahmad R., San Pietro A. (Eds.), Prospects for Biosaline Research, Department of Botany, University of Karachi, Pakistan, 1986, pp. 125-137.

[2] Ahmad M., Rauf A., Makhdum M.I., Studies on salt tolerance of cotton (Gossypium hirsutum L.), Indian J. Agric. Res. 29 (1995) 64-68.

[3] Ahmad S., Exploration of potential sources of salt tolerance in cotton (Gossypium hirsutum L.), Ph.D. thesis, Institute of Pure and Applied Biology, B.Z. University, Multan, Pakistan, 1999.

[4] Ahmad Z., Prospects of cotton culture's retrieval caught up in various circle of virus attack, The Pak Cotton Grower (1998) 4.

[5] Akbar M., Yabuno T., Breeding for saline resistant varieties of rice. IV. Inheritance of delayed type panicle sterility induced by salinity, Japan J. Breed. 27 (1977) 237-240.

[6] Al-Khatib M., McNeilly T., Collins J.C., The potential of selection and breeding for improved salt tolerance in lucerne (Medicago sativa L.), Euphytica 65 (1993) 43-51.

[7] Allen S.K., Dobrenz A.K., Schonhorst M.H., Stoner J.E., Heretability of $\mathrm{NaCl}$ tolerance in germinating alfalfa seeds, Agron. J. 77 (1985) 90-96.

[8] Anthony K., Cotton, Biologist 38 (1991) $121-126$.

[9] Ashraf M., McNeilly T., Exploitation of useful variation for salt tolerance in pearl millet (Pennisetum americanum (L.) Leeke), Plant Breed. 108 (1992) 234-240.

[10] Ashraf M., McNeilly T., Bradshaw A.D., Heritability of $\mathrm{NaCl}$ tolerance in seven grass species, Euphytica 35 (1986) 935-940. 
[11] Ashraf M., McNeilly T., Bradshaw A.D., Selection and heritability of salt tolerance in four grass species, Crop Sci. 227 (1987) 232-234.

[12] Azhar F.M., McNeilly T., The genetic basis of variation for salt tolerance in sorghum bicolor (L.) Moench seedlings, Plant Breed. 101 (1988) 114-121.

[13] Chowdhry T.M., Cotton soils of Pakistan. Cotton in Pakistan. Pak. Central Cotton Committee, Karachi, 1972, pp. 275-305.

[14] Cobley L.S., Steele W.M., Vegetables fibres, in: An Introduction to the Botany of Tropical Crops, Longman, London, 1976, pp. 252-257.

[15] Epstien E., Norlyn J.D., Sea water based crop production: A feasibility study, Science 197 (1977) 249-251.

[16] Furr J.R., Ream C.L., Breeding citrus root stocks for salt tolerance, Proc. 1st. Int. Citrus Symp. 1 (1969) 373-380.

[17] Griffing B., Concept of general and specific combing ability in relation to crossing system, Aust. J. Biol. Sci. 9 (1956) 463-493.

[18] Hayman B.L., The theory and analysis of diallel crosses, Genetics 39 (1954) 789-802.

[19] Jinks J.L., Hayman B.L., The analysis of diallel crosses. Maize Genetics, Crop News Lett. 27 (1953) $48-54$.

[20] Kao H.M., McVetty P.B.E., Quantitative genetic studies of yield, yield components, and phenological and agronomic characters in spring faba bean, Genome 29 (1987) 169-173.

[21] Khan A.N., Qureshi R.H., Ahmad N., Performance of cotton cultivars as affected by types of salinity. I. Growth and yield, Sarhad J. Agric. Sci. 14 (1998) 73-77.

[22] Kolb F.L., Marshall H.G., Hill R.R., Inheritance of traits associated with grain yield in a spring oat diallel, Crop Sci. 30 (1990) 1023-1029.

[23] Ledbetter C.A., Heritability of salt tolerance during germination and emergence in short staple cotton. Dissertation-Abstracts-International, Sci. Eng. 47 (1987) 113.

[24] Lucket D.J., Diallel analysis of yield components, fibre quality and bacterial blight resistance using spaced plants of cotton, Euphytica 44 (1989) 11-21.

[25] Maas E.V., Salt tolerance of plants, Appl. Agric. Res. 19 (1986) 12-26.

[26] Mather K., Jinks J.L., Introduction to Biometrical Genetics, 2nd ed., Chapman and Hall, London, 1982.
[27] Moeljopawiro S., Ikehashi H., Inheritance of salt resistance in rice, Euphytica 30 (1981) 291-300.

[28] Noble C.L., Halloran G.M., West D.W., Identification and selection for salt tolerance in lucerne (Medicago sativa L.), Aust. J. Agric. Res. 35 (1984) 239-252.

[29] Qayyum M.A., Malik M.D., Farm production losses in salt affected soils, in: Managing Soil Resources, Proc. First National Congress of Soil Science, Lahore, Pakistan, 1988, pp. 356-363.

[30] Rafiq M., Soil resources and soil related problems in Pakistan, Symp. on Applied Soil Physics in Stress Environments, 22-26 Jan. 1989, Pakistan Agricultural Research Council, Islamabad, Pakistan, 1990.

[31] Ratanadilok N., Marcarian V., Schmalzel C., Salt tolerance in grain sorghum, Agron. Abst. 70 (1978) 160.

[32] Sajjad M.S., Estimation of heritability and genetic advance in hybrids of rice under saline environment, Pak. J. Sci. Indus. Res. 30 (1987) 664-666.

[33] Shannon M.C., Breeding, selection and the genetics of salt tolerance, in: Staples R.C., Toenniessen G.H. (Eds.), Salinity Tolerance in Plants - Strategies for Crop Improvement, John Wiley and Sons, New York, 1984, pp. 231-254.

[34] Singh R.K., Chaudhary B.D., Biometrical Methods in Quantitative Genetic Analysis, Kalyani Pub., New Delhi, India, 1985.

[35] Steel R.G.D., Torrie J.H., Principles and Procedures of Statistics, McGraw Hill Book Co., Inc., New York, USA, 1984.

[36] Strogonov B.P., Physiological Basis of Salt Tolerance in Plants, I.P.S.T. Jerusalam O. L. Boume Press, London, 1964.

[37] Tal M., Genetics of salt tolerance in higher plants: Theoretical and practical considerations, Plant and Soil 89 (1985) 199-266.

[38] Thomas J.R., Osmotic and specific salt effects on growth of cotton, Agron. J. 72 (1980) 407-412.

[39] Waheed A., Genetic Basis of Salt Tolerance in Chickpea (Cicer arietinum L.) and Lentil (Lens culinaris Medic.), Ph.D. thesis, Department of Botany, B.Z. University, Multan, Pakistan, 1997.

[40] Yates F., The analysis of data from all possible crosses between a set of parental lines, Heredity 1 (1947) 287-301. 